УДК 378:005.6

А. В. Вербицька, к. н. з держ. упр., О. В. Василенко, магістр

\title{
НАПРЯМИ ПІДВИЩЕННЯ АКАДЕМІЧНОЇ ДОБРОЧЕСНОСТІ ЯК СКЛАДОВОЇ ЗАБЕЗПЕЧЕННЯ ЯКОСТІ ВИЩОЇ ОСВІТИ
}

Актуальність теми дослідження. Оновлення концепції вищої освіти передбачає формування у студентів уміння самостійно та відповідально вчитися та займатися науковою діяльністю. В умовах зростаючих вимог до здобувачів вищої освіти помітною $\epsilon$ негативна тенденція недобросовісного виконання норм академічної доброчесності.

Постановка проблеми. Привласнення і використання чужих праць та їх фррагментів не розвиває особистість майбутнього фахівця, гальмує розвиток наукового знання і негативно впливає на освітнє середовище закладу вищої освіти. Відтак, питання формування академічної культури як стилю поведінки учасників освітнього процесу набуває критично важливого значення на всіх освітніх рівнях.

Аналіз останніх досліджень i публікацій. Питанням академічної доброчесності присвячені наукові розробки зарубіжних вчених: Т. Фішман, І. Глендіннінг, Е. Мак-Кланг, Дж. Шнейдер, С. Джордан та інші. У контексті дослідження вагомим є також доробок вітчизняних науковців: Курбатов С.В., Сацик В. І., Семененко Л. П., Семеног О. М., Фініков Т. В., Артюхов А. Є., Чмир О. С. та інші.

Виділення недосліджених частин загальної проблеми. Напрями підвищення академічної доброчесності на основі закордонного досвіду, а також дієві фоорми роботи зі здобувачами вищої освіти у напрямку підвищення їх академічної культури потребують дослідження.

Постановка завдання. Мета статті полягає у визначенні напрямів підвищення академічної доброчесності як складової забезпечення якості вищої освіти.

Виклад основного матеріалу. Тренінг $\epsilon$ найефрективнішою фоормою занять для студентської молоді в аспекті питання академічної доброчесності, оскільки передбачає не лише набуття нових теоретичних знань, а й вироблення практичних навичок в ненав'язливій gaтеформі, що є рушійним фрактором у навчанні з даної тематики. Пройшовши тренінгове заняття з акцентом на юридичну відповідальність за порушення норм академічної доброчесності учасники переосмислили свої погляди у напрямку більш відповідального фрормування своєї академічної культури. Запропонований тренінг дозволив підвищити рівень обізнаності щодо поняття академічної доброчесності, а також юридичної відповідальності за порушення принципів академічної доброчесності та сформувати позитивне ставлення до поширення інформації щодо академічної чесності серед студентів тренінгової групи.

Висновки. Розроблений тренінг "Академічна доброчесність як компетенція фрахівця» спрямований на набуття нових теоретичних знань, а також вироблення практичних навичок в ненав'язливій gaте-формі, що є рушійним фрактором у навчанні молоді з даної тематики.

Ключові слова: академічна доброчесність; якість вищої освіти; треніне; конкуреноспроможний фрахівець.

A. V. Verbytska, Candidate of Sciences in Public Administration, O. V. Vasylenko, Master

\section{DIRECTIONS OF ACADEMIC HONESTY ENHANCING AS A COMPONENT OF ENSURING QUALITY OF HIGHER EDUCATION}

Urgency of the research. The renewal of the concept of higher education involves the formation of students' ability to study and conduct scientific research independently and responsibly. In the context of increasing requirements for higher education graduates, the negative tendency of unfair compliance with the standards of academic integrity is noticeable.

Target setting. The appropriation and usage of the works of others and their fragments does not develop the personality of the future specialist. It limits the development of scientific knowledge and negatively affects the educational environment of higher education institution. Therefore, the question 
of formation of academic culture as a style of behavior of participants in the educational process becomes critical at all educational levels.

Actual scientific researches and issues analysis. The scientific works by such foreign authors as T. Fishman, I. Glendinning, E. McClung, J. Schneider, S. Jordan, etc. are devoted to academic integrity. In the context of the study, there are also significant contributions from such domestic scientists as Kurbatov S. V., Satsyk V. I., Semenenko L. P., Semenoh O. M., Finikov T. V., Artyukhov A. E., Chmyr O. S., etc.

Uninvestigated parts of general matters defining. The directions of increasing academic integrity on the basis of foreign experience, as well as effective forms of work with higher education students in order to enhance their academic culture require research.

The research objective. The purpose of the paper is to identify areas for enhancing academic integrity as a component of quality assurance in higher education.

The statement of basic materials. Training is the most effective form of work with student youth in terms of academic integrity, since it involves not only acquiring new theoretical knowledge but also the development of practical skills in a non-intrusive game-form, which is a driving factor in learning from this subject. After training sessions with a focus on legal responsibility for breaching the rules of academic integrity, participants redefined their views towards a more responsible formation of their academic culture. The proposed training allowed raising the level of awareness about the concept of academic integrity, as well as legal responsibility for violating the principles of academic integrity and forming a positive attitude towards disseminating information about academic honesty among the students of the training group.

Conclusions. The developed training "Academic integrity as a specialist competence" is aimed at acquiring new theoretical knowledge, as well as developing practical skills in a non-intrusive gameform, which is a driving factor in teaching young people on this topic.

Keywords: academic integrity, quality of higher education, training, competitive specialist.

$$
\text { DOI: 10.25140/2412-1185-2019-1(13)-21-28 }
$$

Актуальність теми дослідження. Сучасний освітній процес спрямований на фрормування конкурентоспроможних фрахівців, які не лише володіють актуальними компетенціями, але і прагнуть до постійного професійного та особистісного розвитку. Оновлення концепції вищої освіти передбачає формування у студентів уміння самостійно та відповідально вчитися та займатися науковою діяльністю. В умовах зростаючих вимог до здобувачів вищої освіти помітною $€$ негативна тенденція недобросовісного виконання норм академічної доброчесності.

Вища освіта покликана формувати цінності академічної чесності, реалізуючи тим самим свою соціальну місію. Ігнорування академічних порушень серед викладачів, студентства та наукових діячів призводить до спаду культурної цінності наукових надбань, тим самим знижується рівень суспільно-економічного розвитку. Академічна доброчесність формує індивідуальну репутацію кожного студента та науково-педагогічного працівника зокрема, та закладу вищої освіти загалом. Як наслідок, підвищується інституційна репутація та якість вищої освіти. Університети 3 високим академічним іміджем викликають набагато більше довіри з боку роботодавців та суспільства. Формування нових академічних цінностей сприяє розвитку інноваційної культури, завдяки якій підвищується якість підготовки фахівців та наукових досліджень. Тому сучасні заклади вищої освіти створюють умови для розвитку інноваційного мислення студентів, основною з яких є прищеплення норм академічної доброчесності.

Постановка проблеми. Академічна доброчесність сприяє формуванню фрахівців з критичним та інноваційним мисленням, стимулює творчу активність, ініціативність студентів та розвиває у них почуття відповідальності. У свою чергу, привласнення і використання чужих праць та їх фрагментів не розвиває особистість майбутнього фрахівця, гальмує розвиток наукового знання i негативно впливає на освітнє середовище закладу вищої освіти. Відтак, питання формування академічної культури як стилю поведінки учасників освітнього процесу набуває критично важливого значення на всіх освітніх рівнях.

Аналіз останніх досліджень і публікацій. Питанням академічної доброчесності присвячені наукові розробки зарубіжних вчених: Т. Фішман, І. Глендіннінг, Е. Мак-Кланг, Дж. Шнейдер, С. Джордан [1-4] та інші. У контексті дослідження вагомим $€$ також доробок вітчизняних науковців: Курбатов С. В., Сацик В. І., Семененко Л. П., Семеног О.М., Фініков Т. В., Артюхов А. 
Є., Чмир О. С. [5-10] та інші. Вітчизняні науковці присвятили свої праці різним аспектам академічної доброчесності в рамках сталого розвитку суспільства. Так, О. Чмир зазначає, що академічна доброчесність впливає не лише на якість освіти, а й на цінності та особистісні риси молоді. Авторка наголошує, що формуванню моральних норм академічної чесності у молодих людей сприяє навчання в університетах [10]. Л. Семененко наголошує, що академічна доброчесність впливає не лише на цінності студента, що закладаються під час навчання у вищій школі, а й на підвищення рівня професійної підготовленості [7]. Академічну доброчесність як соціальний капітал також розглядають Т. Добко та В. Турчиновський, які наголошують, що на рівні кожного університету дотримання засад академічної чесності має стати частиною чіткої інституційної політики, підкріпленої запровадженням нової моделі і принципів академічної взаємодії [11].

Виділення недосліджених раніше частин загальної проблеми. Розповсюдження норм та принципів академічної доброчесності, а також належна підтримка їх у практичному вимірі, сприятиме міжнародній співпраці та розвитку української вищої освіти на новому якісному рівні. Для цього, варто адаптовувати досвід іноземних університетів по підготовці конкурентоспроможних фахівців, які б змогли конкурувати на ринку праці, а також використовувати дієві методи у боротьбі з академічним шахрайством. Таким чином, напрями підвищення академічної доброчесності на основі закордонного досвіду, а також дієві форми роботи зі здобувачами вищої освіти у напрямку підвищення їх академічної культури потребують дослідження.

Постановка завдання. Мета статті полягає у визначенні напрямів підвищення академічної доброчесності як складової забезпечення якості вищої освіти. У статті обгрунтовано тренінгову форму роботи зі студентською молоддю на тему «Академічна доброчесність як компетенція фахівця», спрямовану на підвищення обізнаності в питаннях, академічної доброчесності, підвищення мотивації до підтримки цінностей академічної культури.

Виклад основного матеріалу. Професійна підготовка майбутніх фрахівців орієнтується на модель майбутнього спеціаліста як творчої, креативної, відповідальної та культурної особистості. Моральність та фрахові знання майбутніх фрахівців формуються під впливом академічної культури. Дотримання норм академічної доброчесності дозволить розвивати у здобувачів вищої освіти творчий потенціал та критичне мислення.

На підставі попередніх досліджень було визначено першочергові причини, які сприяють процвітанню академічної нечесності в українських закладах вищої освіти: відсутність у здобуваччів вищої освіти досвіду викладення власних думок та відсутність страху перед покаранням за порушення норм академічної доброчесності. Відтак, пропонуємо тренінгову програму навчання академічній доброчесності студентської молоді, що спрямована на пом'якшення вираженості згаданих вище причин.

Тренінг $є$ найефективнішою фрормою занять для студентської молоді в аспекті питання академічної доброчесності, оскільки передбачає не лише набуття нових теоретичних знань, а й вироблення практичних навичок в ненав'язливій game-формі, що $€$ рушійним фактором у навчанні 3 даної тематики. Пройшовши тренінгове заняття 3 акцентом на юридичну відповідальність за порушення норм академічної доброчесності, очікується, що учасники переосмислять свої погляди у напрямку більш відповідального формування своєї академічної культури.

Запропонована тренінгова програма занять «Академічна доброчесність як компетенція фахівця» розроблена та апробована у роботі зі студентами Чернігівського національного технологічного університету. Тренінгові заняття проведено зі студентами, які навчаються на третьому та четвертому курсі, а також на магістратурі. Усього до занять було залуено 125 осіб. Розроблена програма навчання академічної доброчесності студентської молоді $є$ універсальною та може застосовуватися для студентів будь-яких спеціальностей. Метою тренінгу $є$ набуття практичного досвіду та ознайомлення з правильною обробкою наукових джерел без порушень норм академічної доброчесності та поглиблення знань про відповідальність за такі порушення.

Розроблений тренінг навчання академічної доброчесності студентів дозволив:

- детально ознайомитися з провідним українським досвідом протидії порушенню норм академічної доброчесності; 
- дізнатися про юридичну та дисциплінарну відповідальність за порушення та практичні приклади такої відповідальності;

- спробувати на практиці правильно цитувати першоджерела.

- анонімно перевірити за допомогою «Шкали плагіату» унікальність своїх наукових доробків та серйозність порушень норм академічної доброчесності.

Програма тренінгу «Академічна доброчесність як компетенція фрахівця» включає в себе вступну, основну та заключну частини. Вступна частина тренінгу включає знайомство учасників, вироблення разом з ними правил тренінгу, та виявлення очікувань від заняття.

Основна частина тренінгу складається з теоретичного та практичного блоку інформації. Дана частина тренінгу передбачає проведення міні-лекції на тему «Український досвід протидії порушенням норм академічної доброчесності та юридична відповідальність за них». У лекції висвітлено методи боротьби з плагіатом у провідних університетах країни та висвітлено типи академічної відповідальності студентів. Потім студентів ознайомлюють 3 основними актуальними правилами цитування наукових робіт. У цій частині використовуються також рухові вправи на зняття напруги між учасниками тренінгової програми, а також методика $€$. $€$. Тунік для визначення креативності особистості.

У заключній частині тренінгу підводяться підсумків та зворотній зв'язок учасників тренінгу. Кожен учасник висловлює свою об'єктивну думку стосовно виправданих чи невиправданих очікувань від заняття та озвучує зроблені висновки, а також пропозиції.

Критерії ефективності проведеного тренінгу предсталені в таблиці 1.

Отримані результати опитування, яке було проведено до і після тренінгу дали змогу зробити наступні висновки. Більша половина учасників тренінгу (58\%) на початку заняття зазначили, що їм знайоме поняття академічної доброчесності. Не зважаючи на це, при обговоренні виявилось, що знання студентів щодо цього поняття виявилися обмеженими, студенти давали вузькі відповіді. Більшість учасників тренінгу виявили гоовність дотримуватися норм академічної доброчесності як основи професіоналізму фрахівця: 40\% студентів третього курсу та $20 \%$ студентів четвертого та п'ятого курсів (Табл. 2).

Таблиця 1

Критерії ефективності тренінгу «Академічна доброчесність як компетенція фрахівця»

\begin{tabular}{|c|c|}
\hline Критерій & Результат \\
\hline $\begin{array}{l}\text { 1. Підвищення рівня обізнаності щодо поняття академічної доброчесності, а } \\
\text { також юридичної відповідальності за порушення принципів академічної } \\
\text { доброчесності }\end{array}$ & $88,2 \%$ \\
\hline 2. Формування морального образу академічно доброчесного студента & $65,4 \%$ \\
\hline $\begin{array}{l}\text { 3. Формування позитивного ставлення до поширення інформації щодо } \\
\text { академічної чесності серед студентів тренінгової групи }\end{array}$ & $70 \%$ \\
\hline 4. Оцінка успішності тренінгу учасниками & $\begin{array}{l}« 4 »-68 \% \\
« 5 »-32 \%\end{array}$ \\
\hline
\end{tabular}

Таблиця 2

Визначення відсотка бажання у дотриманні академічних норм та правил цитування

\begin{tabular}{|l|c|c|c|}
\hline \multirow{2}{*}{ Варіанти відповідей } & \multicolumn{2}{|c|}{ Відповіді студентів у \% } & \multirow{2}{*}{$\%$} \\
\cline { 2 - 4 } а) Так, хочу, адже це покращить рівень мого професіоналізму & $40 \%$ & $20 \%$ & $60 \%$ \\
\hline $\begin{array}{l}\text { б) Так, хочу, але це дуже складно, тому простіше не } \\
\text { дотримуватися цих правил }\end{array}$ & $10 \%$ & $18 \%$ & $28 \%$ \\
\hline в) Ні, не хочу, адже це ніяк некарається & $0 \%$ & $12 \%$ & $12 \%$ \\
\hline
\end{tabular}

Також проведеним анкетуванням було визначено, що тренінговій групі студентів не відомо, який проект став основоположним рушієм у боротьбі з плагіатом в українському досвіді протидії порушенням норм академічної доброчесності (92\%), лише 8\% припустили, що цим рушієм міг стати проект SAIUP.

У ході тренінгу студентам було запропоновано ознайомитись зі «Шкалою плагіату», яку було розроблено за підтримки Проекту сприяння академічній доброчесності в Україні SAIUP [12], а 
також використати її на практиці для того, щоб визначити власний різновид порушень правил цитування. Було визначено, що значна частина студентів не знає про існування даної шкали $(32 \%)$, більша частина учасників зазначили, що вони ознайомлені 3 даною шкалою, але не визначали власний різновид порушень (44\%).

Найпоширенішим різновидом порушень серед учасників тренінгу визначено «Непопадання» $30,2 \%$. Це вказувало на те, що студентська молодь припускалась помилок у цитуванні інших авторів, типовими помилками ставали зазначення не тих авторів у переліку посилань, а також те, що у своїх власних роботах студенти використовували хибні фрази.

Іншим поширеним різновидом став - «Мозаїка» (20,9\%). Тобто, студенти, у яких визначився даний варіант були загалом згодні 3 тим, що незважаючи на правильне цитування першоджерел, власних думок та ідей у своїх наукових роботах використовували замало.

Рівна кількість осіб отримала «Цитування привидів» і «Вибирання родзинок» - по 12,5\%. «Цитування привидів» обумовлено тим, що в наукових доробках студентів використовувалися джерела, яких не існує або ж інформація, яку не зазначено в першоджерелі. Щодо «Вибирання родзинок» то це в Шкалі плагіату більш серйозне порушення і воно означає, що студенти описували основну ідею або використовували конкретні терміни без посилання на них у переліку використаної літератури. «Мітоз», «Випадкова недостовірність», «Викривлення» зустрічаються рідше серед учасників тренінгу (по 8,3\%). «Мітоз» являється важким різновидом порушення у написанні наукових доробок, яка являє собою копіювання власних наукових робіт написаних у минулому для повторної публікації, без вказування посилання на самого себе. «Викривлення» передбачає переписування тексту з першоджерела на свій лад або ж цитування неіснуючого автора. «Випадкова недостовірність» являється найлегшим видом порушення академічної чесності. Передбачає оформлення першоджерел за всіма правилами, але інколи не зазначали літературу забуваючи вказати номери сторінок або назву використаного видання. Отже, кожен зі студентів-учасників заняття виявив те, що в будь якій мірі припускався порушень правил цитування першоджерел. Результати діагностики за Шкалою свідчать, що серйозність порушень виявляється високою.

Після проведення тренінгового заняття визначали зміни у ставленні до поняття академічної чесності. Так, 76\% опитаних зазначили, що недотримання академічної чесності, являється проблемою, яка впливає, як на рівень та якість освіти, так і на фрормування компетентного фахівця.

Було визначено думку студентів стосовно того, що $є$ запорукою успіху у дотриманні академічної чесності здобувачами освіти (Рис. 1). Так, студенти 3 курсу вбачають це у перевірці власних робіт на рівень в них унікальності через систему виявлення плагіату (60\%); студенти 4 курсу зазначили, що ефективнішим способом буде дотримання норм законодавства, яке регулює відносини стосовно академічної чесності (55\%). На думку майбутніх магістрів, запорукою успіху $€$ надання достовірної інфрормації про результати власної навчальної діяльності (52\%).

Після завершення тренінгу студенти також отримали вихідні анкети для того, щоб проаналізувати ефективність отриманої інформації. Усі учасники (100\%) були згодні з тим, що отримана інформація буде корисною для них у майбутньому.

У ході тренінгового заняття «Академічна доброчесність як компетенція фахівця» учасникам також було запропоновано пройти методику оцінки рівня креативності Є.Є. Тунік.

У дослідженні використано сукупний середній бал рівня креативності. Виділено три рівні креативності відповідно до отриманих балів:

- високий (швидкість перебігу процесів мислення являється значною, гарна пам'ять, наявне бажання досліджувати та аналізувати нові об'єкти, наявне вміння виробляти різноманітні ідеї для розв'язання критичних ситуацій, проявляє наполегливість у досягненні своєї мети, уміють накопичувати позитивний досвід, у своїй роботі чесний, тактовний);

- середній (мають необхідний креативний потенціал, але не використовують його в повній мірі, різні інтереси, у виконанні покладених на них обов'язків - відповідальні, інколи генерують оригінальні ідеї);

- низький (отримані завдання виконує шаблонно, не проявляє ініціативи у вирішенні проблем з якими стикається, не подобається вирішування складних завдань, притаманне 
стереотипне мислення, не мають мотивації до освітньої самореалізації, уява та франтазія погано розвинена).
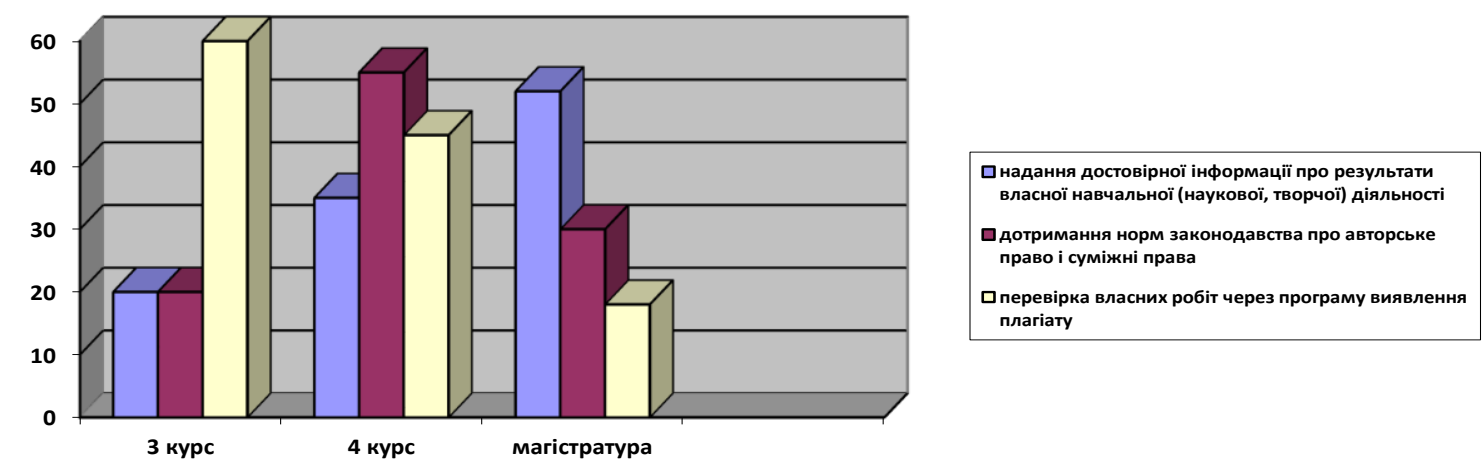

Рис. 1 Запорука успіху у дотриманні академічної доброчесності (на думку здобувачів вищої освіти), \%

За результатами проведеного тестування майже половина учасників (52\%) володіє низьким рівнем креативності, що характеризується шаблонним мисленням у розв'язанні поставлених завдань, незацікавленістю у отриманні нових знань, нейтральним ставлення до навчального процесу. Із цього випливає, що студентська молодь має низький рівень практичних знань і умінь стосовно вироблення потенційно важливих ідей для аналізу конкретних досліджень. Для того, щоб отримати позитивний досвід у розвитку креативної компетентності, необхідно конструювати та вирішувати спеціальні ситуації, що вимагають творчого підходу і створювати умови для його реалізації. Креативність являється наріжним каменем у написанні наукових робіт. Адже, творці наукових творів у своїй діяльності повинні уміти не тільки знаходити інформацію та аналізувати iï, а також критично та креативно мислити.

Популярним та ефективним способом розвитку креативності $€$ тренінг, оскільки у ході відпрацювання навичок креативності ставиться акцент на групову взаємодію та особистісний ріст, відповідно розвиваються і творчі якості: усвідомленість, оригінальність, незалежність, схильність до ризику, інтуїтивність. Ці характеристики цінуються в умовах професійного самовдосконалення та допоможуть майбутнім фрахівцям бути на сучасному ринку праці конкурентоспроможними. Особливе значення має використання тренінгу студентами заради формування особистісних професійно значущих якостей. Саме за допомогою групової форми роботи здійснюється актуалізація прояву особистісних якостей та їх розвиток. Таким чином, пізнання особливостей критичного мислення, з'ясування особливостей розвитку креативних здібностей у студентів можливе шляхом запровадження курсів розвитку креативного мислення.

Як правило, для гуманітарних дисциплін питання академічної доброчесності студентів $€$ більш актуальним. Студенти різних спеціальностей з перших курсів долучаються до науководослідної роботи, яка передбачає вивчення груп клієнтів/споживачів, їх потреб, проблем у різних сорерах, розробку різних рекомендацій тощо. Враховуючи відносно нещодавнє усвідомлення важливості академічної доброчесності у науковій діяльності, треба, щоб ці знання поширювалися та були актуальними. Фахову підготовку сучасних студентів пронизує академічна культура, у рамках якої фрормуються професійні та особистісні якості.

Висновки. Розроблений тренінг «Академічна доброчесність як компетенція фрахівця» спрямований на набуття нових теоретичних знань, а також вироблення практичних навичок в ненав'язливій game-фрормі, що $є$ рушійним фрактором у навчанні молоді 3 даної тематики. Пройшовши тренінгове заняття з акцентом на юридичну відповідальність за порушення норм академічної доброчесності учасники переосмислили свої погляди у напрямку більш відповідального формування своєї академічної культури. Запропонований тренінг дозволив підвищити рівень обізнаності щодо поняття академічної доброчесності, а також юридичної 
відповідальності за порушення принципів академічної доброчесності та сформувати позитивне ставлення до поширення інфрормації щодо академічної чесності серед студентів тренінгової групи.

Запропоновано механізми удосконалення знань щодо академічної доброчесності серед здобувачів вищої освіти:

- створення центру з академічної доброчесності, який займається визначенням стандартів чесності та контролю за ним в університетах;

- введення системної перевірки наукових робіт;

- введення тренінгових програм та спеціальних навчальних модулів;

- запровадження іспитів на знання основ академічної доброчесності;

- дотримання виконання санкцій, застосованих до академічного шахраювання.

Проведене дослідження не вичерпує усіх аспектів проблеми. Перспективними є такі напрями подальших наукових пошуків: конкретизація мети та розробка прийомів і засобів щодо поширення академічної доброчесності; впровадження сучасних форм роботи, нових технологій 3 метою покращення знань щодо академічної чесності серед здобувачів вищої освіти.

\section{Література}

1. Fishman, T. The Fundamental Values of Academic Integrity (2nd edition). International Center for Academic Integrity, Clemson University. [Electronic resource] / Fishman T.. - 2012. - Access mode: http://www.academicintegrity. org/icai/assets/AUD_Integrity_Quotes.pdf.

2. Glendinning, I. Promoting Maturity in Policies for Plagiarism across Europe and beyond. [Electronic resource] / Glendinning I.. - 2018. - Access mode:https://www.coe.int/t/DG4/EDUCATION/etined//rene_Glendinning_ PragueForum2015.pdf.

3. McClung, E. L., \& Schneider J. K. Concept Synthesis of Academically Dishonest Behaviors. Journal of Academic Ethics / McClung E. L., \& Schneider J. K.. // № 15. - 2016. - P. 3-7.

4. Jordan, S. R. Conceptual Clarification and the Task of Improving Research on Academic Ethics. Journal of Academic Ethics. / Jordan, S. R. - 2015. - P. 240-242.

5. Курбатов, С.В. Академічна доброчесність як імператив виживання університетської спільноти [Електронний ресурс] / С. В. Курбатов. - 2016. - Режим доступу до ресурсу: http://studyinukraine.gov.ua/wp-content/uploads/2018/03/ Kurbatov.pdf.

6. Сацик, В. І. Академічна доброчесність: міфічна концепція чи дієвий концепт [Електронний ресурс] / В. І. Сацик // SAIUP. - 2017. - Режим доступу до ресурсу: http://www.saiup.org.ua/novyny/akademichna-dobrochesnist-mifichnakontseptsiya-chy-diyevyj-kontsept/.

7. Семененко, Л. П. Академічна доброчесність - запорука якісної освіти [Електронний ресурс] / Л. П. Семененко. 2016. - Режим доступу до ресурсу:http://repository.kpi.kharkov.ua/bitstream/KhPIPress/27252/1/2016_ Semenenko Akademichna dobrochesnist.pdf.

8. Семеног, О. М. Академічна культура - основа дослідницького навчання в університеті / О. М. Семеног, О. В. Семеніхіна. - Суми: СумДПУ ім. А. С. Макаренка, 2017. - 232 с.

9. Фініков, Т. В. Академічна чесність як основа сталого розвитку університету / Т. В. Фініков, А. Є. Артюхов. - Київ: Таксон, 2016. - $234 \mathrm{c}$.

10. Чмир, О. С. Національний репозитарій академічних текстів. Запобігання та протидія академічному плагіату у ВНЗ [Електронний ресурс] / О. С. Чмир // УкрIHTEI. - 2017. - Режим доступу до ресурсу: http://www.uintei.kiev. ua/images/files/2017/podii/2017-05/Prezent_Chmir.pdf.

11. Добко, Т. В. Академічна культура та доброчесність як соціальний капітал сучасного університету [Електронний ресурс] / Т. В. Добко, В. Р. Турчиновський. - 2016. - Режим доступу до ресурсу: http://www.univer.kharkov.ua /images/redactor/news/2016-09-07/chesnist osnova rozvitk Univers.pdf.

12. Чи я плагіював? "Шкала плагіату” [Електронний ресурс] - 2017. - Режим доступу до ресурсу: https://saiup.org.ua /resursy/chy-ya-plagiyuvav-shkala-plagiatu/a.

\section{Reference}

1. Fishman, T. (2012). The Fundamental Values of Academic Integrity (2nd edition). International Center for Academic Integrity, Clemson University. Retrieved from http://www.academicintegrity.org/icai/assets/AUD_Integrity_Quotes.pdf [in English].

2. Glendinning, I. (2018). Promoting Maturity in Policies for Plagiarism across Europe and beyond. Retrieved from https://www.coe.int/t/DG4/EDUCATION/etined//rene_Glendinning_PragueForum2015.pdf [in English].

3. McClung, E. L., \& Schneider, J. K. (2016). Concept Synthesis of Academically Dishonest Behaviors. Journal of Academic Ethics, 15, 3-7 [in English].

4. Jordan, S. R. (2015). Conceptual Clarification and the Task of Improving Research on Academic Ethics. Journal of Academic Ethics, 15, 240-242 [in English].

5. Kurbatov, S. V. (2016). Akademichna dobrochesnist yak imperatyv vyzhyvannia universytetskoii spilnoty [Academic integrity as an imperative of survival for an academic community]. studyinukraine.gov.ua. Retrieved from http://studyinukraine.gov.ua/wp-content/uploads/2018/03/Kurbatov.pdf [in Ukrainian].

6. Satsyk, V. I. (2017). Akademichna dobrochesnist: mifichna konceptsiia chy diievyi kontsept [Academic integrity: mythical conception or effective concept]. www.saiup.org.ua. Retrieved from http://www.saiup.org.ua/novyny/akademichnadobrochesnist-mifichna-kontseptsiya-chy-diyevyj-kontsept/ [in Ukrainian]. 
7. Semenenko, L. P. (2016). Akademichna dobrochesnist - zaporuka yakisnoii osvity [Academic integrity - precondition for quality education]. repository.kpi.kharkov.ua. Retrieved from http://repository.kpi.kharkov.ua/bitstream/KhPIPress /27252/1/2016_Semenenko_Akademichna_dobrochesnist.pdf [in Ukrainian].

8. Semenoh, O. M. \& Semenikhina, O. V. (2017). Akademichna kultura-osnova doslidnytskoho navchannia $v$ universyteti [Academic culture - a base for research training at the university]. Sumy: SumDpu im. A.S. Makarenka [in Ukrainian].

9. Finikov, T. V. \& Artiukhov, A. Ye. (2016). Akademichna chesnist yak osnova staloho rozvytku universytetu [Academic honesty as a base for university's sustainable development]. Kyiv: Takson [in Ukrainian].

10. Chmyr, O. S. (2017). Natsionalnyi repozytarii akademichnykh tekstiv. Zapobihannia ta protydiia akademichnomu plahiatu u VNZ. [National repository of academic texts. Prevention and counteraction to academic plagiarism in universities]. www.uintei.kiev.ua. Retrieved from http://www.uintei.kiev.ua/images/files/2017/podii/2017-05/Prezent_Chmir.pdf [in Ukrainian].

11. Dobko, T. V. \& Turchynovskyi, V. R. (2016). Akademichna kultura ta dobrochesnist yak sotsialnyi kapital suchasnoho universytetu. [Academic culture and integrity as a social capital of a modern university]. www.univer.kharkov.ua. Retrieved from http://www.univer.kharkov.ua/images/redactor/news/2016-09-07/chesnist_osnova_rozvitk_Univers.pdf. [in Ukrainian].

12. Chy ya plahiyuvav? "Shkala plahiatu" [Did I plagiarize? "Scale of Plagiarism"]. (2017). saiup.org.ua. Retrieved from https://saiup.org.ua/resursy/chy-ya-plagiyuvav-shkala-plagiatu/a [in Ukrainian].

Надійшла 03.03.2019

Бібліографічний опис для цитування :

Вербицька, А. В. Напрями підвищення академічної доброчесності як складової забезпечення якості вищої освіти / А. В. Вербицька, О. В. Василенко // Проблеми соціальної роботи: філософія, психологія, соціологія. - 2019. - № 1 (13). - C. 21-28. 